\title{
Attitude of Parents (Father \& Mother) Towards Visually Impaired Students of Secondary Level in "Education"
}

\author{
Palash chakraborty : Reaserch Scholar (Seacom Skills University) \\ Dr. Debasish Dhar. Associate Prof. of Seacom Skills University
}

\begin{abstract}
Children with visually impaired may face difficulties that result in their experiencing emotional disturbance. There are very reasons for mood disorder among children with visual loss, such as feeling loneliness, avoidance to appear to learn in formal schools and greater dependency on help.
\end{abstract}

According to RCI Act,1992 responsibility for visual disabilities including low vision and blindness PWD Act,1995 proposed the provision of improve educational services, medical care, vocational learning ,employment and social security for all persons with disabilities including blind and low vision.

There are two educational systems for children with visually impaired 1. education in special schools 2 . education in inclusive schools.

The attitude of parents towards visually impaired students are very important in case of of their visually impaired children. The purpose of the study was to find out the attitude of parents(father $\&$ mother) to visually impaired students of class 9 standard. 20 visually impaired students of class 9 were taken for the study. Survey method was adopted to study the attitude of parents (father \& mother) towards visually impaired students of secondary level and attitude scale were taken as tools \& techniques.For the study the samples are taken from two blind schools of Kolkata.

It was found that attitudes(father\& mother) are favourable towards the visually impaired students of secondary level. They are very much sympathetic for the education of the their visually impaired sons or daughter.

Keywords:- Parental Attitude (father \& mother), Visually Impaired Students, Secondary Level.

\section{INTRODUCTION}

Education is the foundation of developing individuals by providing knowledge regarding all over development of human being. There are open doors of opportunities for individuals to achieve better prospects in career growth. Gaining education enhances the individuals to gain respectful life in the society. This is because education offers a setting in which culture and values of a society are developed. The education is not only limited for the visually impaired children but also it is necessary for the children with other disabilities like auditory, learning etc.

Regular participation in education is required for children with visually impaired i.e where blind or low vision children get proper degree of secondary level. When given equal opportunities child with visually impaired may have the potential to take popular education comparable to those of these sighted peers. The opportunities are to be given by the parents (father $\&$ mother) for the individual development of visually impaired student of secondary level.

In era of Inclusive settings, all child whether exceptional or normal are educated together in regular classes of the mainstream schools. Due to lack of knowledge in technology, technology disabled children were initially treated as unwanted and segregated from other normal children. Later their education was carried out in special schools. In recent times there has been a shift towards children with visually impaired to attend the same schools with non disabled children. But due to unavailability of proper infrastructure \& well trained teachers, the children with visually impaired face different problems in inclusive schools having both normal \& visual impaired children. For this reason the investigators selected the two blind schools of Kolkata. They attempt to study "ATTITUDES OF PARENTS (FATHER \& MOTHER)TOWARDS VISUALLY IMPAIRED STUDENTS OF SECONDARY LEVEL IN EDUCATION"

Objectives: To find out

- To study the difference in attitude towards visually impaired student among fathers \& mothers of school 1.

- To study the difference in attitude towards visually impaired students among fathers \& mothers of school 2

- To study the difference in attitude towards visually impaired student among fathers of school 1 \& 2 .

- To study the difference in attitude towards visually impaired student among mothers of school $1 \& 2$.

- To study the difference in attitude of fathers of 2 schools \& mothers of 2 schools towards visually impaired children. 


\section{Hypothesis:}

- H01:There exists no significant difference in attitude towards visually impaired students of secondary level between father \& mother of school 1 .

- H02: There exists no Significant difference in attitude towards visually impaired students of secondary level between father \& mother of school 2.

- H03: There exists no significant difference in attitude towards visually impaired students of secondary level between father of school $1 \&$ school 2

- H04: There exists no significant difference in attitude towards visually impaired students of secondary level between mother of school $1 \&$ school 2 .

- H05: There exists no significant difference in attitude towards visually impaired students of secondary level between father of 2 schools \& mother of 2 schools.

\section{METHODOLOGY}

- Populations: Visually impaired students of secondary level of two blind schools of West Bengal.

- Sample: Two schools ( Narendrapur Blind Boys' Academy and Lighthouse for the blind) having 20 visually impaired students of class 9 (10 from each schools, 10 male and 10 female students) were taken for the study. The schools are government sponsored and no cost is borne by the parents as tuition and hostel fees.

- Method: Survey method was adopted.

Tools \& Techniques:

- Attitude scale of parents ( self made having five options).

- Statistical analysis.

V Variables:

- Dependent; visually impaired students

- Independent:

$\checkmark$ Father's attitude.

$\checkmark$ Mother's attitude

Procedure: Attitude scale (self made) having 5 items were taken.Constructive validity was made by 2 assistant professors who are expert in this field. The five statements were administered to ten (10) fathers of ten (10) blind students and ten (10) mothers of ten (10) blind students. Attitude scale having 5 point (Strongly Agree, Agree, No Comments, Disagree, Strongly Disagree) was taken.

\section{Data Regarding the Statement}

S1 means school (Narendrapur Blind Boys' Academy).

S2 means school (Light House or the blind).

F means father of the students of respective schools. M means mother of the students of respective schools.

Statement - 1 (Table-1): I have no hesitation regarding the education of my blind child.

$S_{1} F \& S_{1} M$

\begin{tabular}{|c|c|c|c|c|c|c|c|}
\hline & SA & A & NC & D.A. & S.D.A & Total & Chi square \\
\hline $\mathrm{S}_{1} \mathrm{~F}$ & 5 & 2 & 1 & 1 & 1 & 10 & \\
\hline $\mathrm{S}_{1} \mathrm{M}$ & 6 & 3 & 1 & 0 & 0 & 10 & \\
\hline Total & 11 & 5 & 2 & 1 & 1 & 20 & 2.9 \\
\hline
\end{tabular}

Table 1

Statement-2 (Table-2): I am very much sympathetic for the education of my blind child . $S_{1} F \& S_{1} M$

\begin{tabular}{|c|c|c|c|c|c|c|c|}
\hline & SA & A & NC & D.A. & S.D.A & Total & Chi square \\
\hline $\mathrm{S}_{1} \mathrm{~F}$ & 6 & 2 & 0 & 1 & 1 & 10 & \\
\hline $\mathrm{S}_{1} \mathrm{M}$ & 8 & 1 & 0 & 1 & 0 & 10 & \\
\hline Total & 14 & 3 & 0 & 2 & 1 & 20 & 2.6 \\
\hline
\end{tabular}

Table 2

Statement - 3 (Table-3): I want to give all opportunities for the education of my blind child. $\mathrm{S}_{1} \mathbf{F} \& \mathrm{~S}_{1} \mathrm{M}$

\begin{tabular}{|c|c|c|c|c|c|c|c|}
\hline & SA & A & NC & D.A. & S.D.A & Total & Chi square \\
\hline $\mathrm{S}_{1} \mathrm{~F}$ & 6 & 2 & 0 & 1 & 1 & 10 & \\
\hline $\mathrm{S}_{1} \mathrm{M}$ & 7 & 1 & 1 & 1 & 0 & 10 & \\
\hline Total & 13 & 3 & 1 & 2 & 1 & 20 & 2.38 \\
\hline
\end{tabular}

Table 3 
Statement-4 (Table-4): I think that tuition is required for my blind child .

$S_{1} F \& S_{1} M$

\begin{tabular}{|c|c|c|c|c|c|c|c|}
\hline & SA & A & NC & D.A. & S.D.A & Total & Chi square \\
\hline $\mathrm{S}_{1} \mathrm{~F}$ & 5 & 3 & 0 & 1 & 1 & 10 & \\
\hline $\mathrm{S}_{1} \mathrm{M}$ & 6 & 2 & 1 & 1 & 0 & 10 & \\
\hline Total & 11 & 5 & 1 & 2 & 1 & 20 & 3.0 \\
\hline
\end{tabular}

Table 4

Statement - 5 (Table-5): I do not want that my blind child participate in different curricular activities. $\mathrm{S}_{1} \mathbf{F} \& \mathrm{~S}_{\mathbf{1}} M$

\begin{tabular}{|c|c|c|c|c|c|c|c|}
\hline & SA & A & NC & D.A. & S.D.A & Total & Chi square \\
\hline $\mathrm{S}_{1} \mathrm{~F}$ & 5 & 2 & 1 & 1 & 1 & 10 & \\
\hline $\mathrm{S}_{1} \mathrm{M}$ & 6 & 2 & 0 & 1 & 1 & 10 & 20 \\
\hline Total & 11 & 4 & 1 & 2 & 2 & 1.8 \\
\hline
\end{tabular}

Table 5

Therefore H01 having five statement are accepted i.e. there exists no difference between of their father s \& mother s of school 1 towards his or her visually impaired child.

Statement-1 (Table-6): I have no hesitation regarding the education of my blind child .

$\mathrm{S}_{2} \mathbf{F} \& \mathrm{~S}_{2} \mathrm{M}$

\begin{tabular}{|c|c|c|c|c|c|c|c|}
\hline & SA & A & NC & D.A. & S.D.A & Total & Chi square \\
\hline $\mathrm{S}_{2} \mathrm{~F}$ & 4 & 4 & 1 & 1 & 0 & 10 & \\
\hline $\mathrm{S}_{2} \mathrm{M}$ & 6 & 3 & 1 & 0 & 0 & 10 & \\
\hline Total & 10 & 7 & 2 & 1 & & 20 & 3.17 \\
\hline
\end{tabular}

Table 6

Statement - 2 (Table-7): I am very much sympathetic for the education of my blind child.

$\mathbf{S}_{2} \mathbf{F} \& \mathbf{S}_{2} \mathbf{M}$

\begin{tabular}{|c|c|c|c|c|c|c|c|}
\hline & SA & A & NC & D.A. & S.D.A & Total & Chi square \\
\hline $\mathrm{S}_{2} \mathrm{~F}$ & 6 & 2 & 0 & 1 & 1 & 10 & \\
\hline $\mathrm{S}_{2} \mathrm{M}$ & 7 & 1 & 0 & 1 & 1 & 10 & 20 \\
\hline Total & 13 & 3 & 0 & 2 & 2 & 1.92 \\
\hline
\end{tabular}

Table 7

Statement-3 (Table-8): I want to give all opportunities for the education of my blind child.

$\mathbf{S}_{2} \mathbf{F} \& \mathbf{S}_{2} \mathbf{M}$

\begin{tabular}{|c|c|c|c|c|c|c|c|}
\hline & SA & A & NC & D.A. & S.D.A & Total & Chi square \\
\hline $\mathrm{S}_{2} \mathrm{~F}$ & 5 & 3 & 0 & 1 & 1 & 10 & \\
\hline $\mathrm{S}_{2} \mathrm{M}$ & 4 & 5 & 0 & 1 & 0 & 10 & \\
\hline Total & 9 & 8 & 0 & 2 & 1 & 20 & 3.5 \\
\hline
\end{tabular}

Table 8

Statement - 4 (Table-9): I think that tuition is required for my blind child.

$\mathrm{S}_{2} \mathbf{F} \& \mathrm{~S}_{2} \mathbf{M}$

\begin{tabular}{|c|c|c|c|c|c|c|c|}
\hline & SA & A & NC & D.A. & S.D.A & Total & Chi square \\
\hline $\mathrm{S}_{2} \mathrm{~F}$ & 4 & 3 & 2 & 1 & 0 & 10 & \\
\hline $\mathrm{S}_{2} \mathrm{M}$ & 6 & 2 & 1 & 1 & 0 & 10 & \\
\hline Total & 10 & 5 & 3 & 2 & 0 & 20 & 1.92 \\
\hline
\end{tabular}

Table 9 
Statement-5 (Table-10): I do not want that my blind child participate in different curricular activites.

$\mathbf{S}_{2} \mathbf{F} \& \mathbf{S}_{2} \mathbf{M}$

\begin{tabular}{|l|l|l|l|l|l|l|l|}
\hline & SA & A & NC & D.A. & S.D.A & Total & Chi square \\
\hline $\mathrm{S}_{2} \mathrm{~F}$ & 3 & 1 & 1 & 1 & 4 & 10 & \\
\hline $\mathrm{S}_{2} \mathrm{M}$ & 5 & 2 & 1 & 1 & 1 & 10 & \\
\hline Total & 8 & 3 & 2 & 2 & 5 & 20 & 2.62 \\
\hline
\end{tabular}

Table 10

Therefore $\mathbf{H O}_{2}$ having five statement are accepted i.e. there exists no difference between of father \& mother of school 2towards his or her visually impaired child.

Statement -1 (Table-11): I have no hesitation regarding the education of my blind child.

$\mathrm{S}_{1} \mathbf{F} \& \mathrm{~S}_{2} \mathbf{F}$

\begin{tabular}{|c|c|c|c|c|c|c|c|}
\hline & SA & A & NC & D.A. & S.D.A & Total & Chi square \\
\hline $\mathrm{S}_{1} \mathrm{~F}$ & 5 & 2 & 1 & 1 & 1 & 10 & \\
\hline $\mathrm{S}_{2} \mathrm{~F}$ & 4 & 4 & 1 & 1 & 8 & 10 & \\
\hline Total & 9 & 6 & 2 & 2 & 9 & 20 & 2.6 \\
\hline
\end{tabular}

Table 11

Statement-2 (Table-12): I am very much sympathetic for the education of my blind child.

$S_{1} F \& S_{2} F$

\begin{tabular}{|c|c|c|c|c|c|c|c|}
\hline & SA & A & NC & D.A. & S.D.A & Total & Chi square \\
\hline $\mathrm{S}_{1} \mathrm{~F}$ & 6 & 2 & 0 & 1 & 1 & 10 & \\
\hline $\mathrm{S}_{2} \mathrm{~F}$ & 6 & 2 & 0 & 1 & 1 & 10 & 20 \\
\hline Total & 12 & 4 & 0 & 2 & 2 & 1.0 \\
\hline
\end{tabular}

Table 12

Statement -3 (Table-13): I want to give all opportunities for the education of my blind child.

$S_{1} F \& S_{2} F$

\begin{tabular}{|c|c|c|c|c|c|c|c|}
\hline & SA & A & NC & D.A. & S.D.A & Total & Chi square \\
\hline $\mathrm{S}_{1} \mathrm{~F}$ & 6 & 2 & 0 & 1 & 1 & 10 & \\
\hline $\mathrm{S}_{2} \mathrm{~F}$ & 5 & 3 & 0 & 1 & 1 & 10 & 20 \\
\hline Total & 11 & 5 & 0 & 2 & 2 & 2.0 \\
\hline
\end{tabular}

Table 13

Statement-4 (Table-14): I think that tuition is required for my blind child.

$\mathbf{S}_{1} \mathbf{F} \& \mathbf{S}_{2} \mathbf{F}$

\begin{tabular}{|c|c|c|c|c|c|c|c|}
\hline & SA & A & NC & D.A. & S.D.A & Total & Chi square \\
\hline $\mathrm{S}_{1} \mathrm{~F}$ & 5 & 3 & 0 & 1 & 1 & 10 & \\
\hline $\mathrm{S}_{2} \mathrm{~F}$ & 4 & 3 & 2 & 1 & 1 & 10 & 20 \\
\hline Total & 9 & 6 & 2 & 2 & 2 & 4.0 \\
\hline
\end{tabular}

Table 14

Statement -5 (Table-15): I do not want that my blind child participate in different curricular activities.

$S_{1} F \& S_{2} F$

\begin{tabular}{|c|c|c|c|c|c|c|c|}
\hline & SA & A & NC & D.A. & S.D.A & Total & Chi square \\
\hline $\mathrm{S}_{1} \mathrm{~F}$ & 5 & 2 & 1 & 1 & 1 & 10 & \\
\hline $\mathrm{S}_{2} \mathrm{~F}$ & 3 & 1 & 1 & 1 & 4 & 10 & \\
\hline Total & 8 & 3 & 2 & 2 & 5 & 20 & 2.62 \\
\hline
\end{tabular}

Table 15 
Therefore $\mathrm{HO}_{3}$ having five statement are accepted i.e. there exists no difference between father of school $1 \&$ father of school 2 his or her visually impaired child.

Statement-1 (Table-16): I have no hesitation regarding the education of my blind child.

$\mathbf{S}_{1} \mathbf{M} \& \mathbf{S}_{2} \mathbf{M}$

\begin{tabular}{|c|c|c|c|c|c|c|c|}
\hline & SA & A & NC & D.A. & S.D.A & Total & Chi square \\
\hline $\mathrm{S}_{1} \mathrm{M}$ & 6 & 3 & 1 & 0 & 0 & 10 & \\
\hline $\mathrm{S}_{2} \mathrm{M}$ & 6 & 3 & 1 & 0 & 0 & 10 & \\
\hline Total & 12 & 6 & 2 & 0 & 0 & 20 & 2.0 \\
\hline
\end{tabular}

Table 16

Statement -2 (Table-17): I am very much sympathetic for the education of my blind child.

$\mathrm{S}_{1} M$ \& $\mathbf{S}_{2} \mathbf{M}$

\begin{tabular}{|c|c|c|c|c|c|c|c|}
\hline & SA & A & NC & D.A. & S.D.A & Total & Chi square \\
\hline $\mathrm{S}_{1} \mathrm{M}$ & 8 & 1 & 0 & 1 & 0 & 10 & \\
\hline $\mathrm{S}_{2} \mathrm{M}$ & 7 & 1 & 0 & 1 & 1 & 10 & \\
\hline Total & 15 & 2 & 0 & 2 & 1 & 20 & 2.6 \\
\hline
\end{tabular}

Table 17

Statement-3 (Table-18): I want to give all opportunities for the education of my blind child.

$S_{1} M \& S_{2} M$

\begin{tabular}{|l|l|l|l|l|l|l|l|}
\hline & SA & A & NC & D.A. & S.D.A & Total & Chi square \\
\hline $\mathrm{S}_{1} \mathrm{M}$ & 7 & 1 & 1 & 1 & 0 & 10 & \\
\hline $\mathrm{S}_{2} \mathrm{M}$ & 4 & 5 & 0 & 1 & 0 & 10 & \\
\hline Total & 11 & 6 & 1 & 2 & 0 & 20 & 5.46 \\
\hline
\end{tabular}

Table 18

Statement -4 (Table-19): I think that tuition is required for my blind child.

$\mathbf{S}_{1} \mathbf{M} \& \mathbf{S}_{2} \mathbf{M}$

\begin{tabular}{|c|c|c|c|c|c|c|c|}
\hline & SA & A & NC & D.A. & S.D.A & Total & Chi square \\
\hline $\mathrm{S}_{1} \mathrm{M}$ & 6 & 2 & 1 & 1 & 0 & 10 & 10 \\
\hline $\mathrm{S}_{2} \mathrm{M}$ & 6 & 2 & 1 & 1 & 0 & 20 & 1.0 \\
\hline Total & 12 & 4 & 2 & 2 & 0 & 20 \\
\hline
\end{tabular}

Table 19

Statement -5 (Table-20): I do not want that my blind child participate in different co curricular activities. $\mathrm{S}_{1} \mathrm{M} \& \mathrm{~S}_{2} \mathrm{M}$

\begin{tabular}{|c|c|c|c|c|c|c|c|}
\hline & SA & A & NC & D.A. & S.D.A & Total & Chi square \\
\hline $\mathrm{S}_{1} \mathrm{M}$ & 6 & 2 & 0 & 1 & 1 & 10 & 10 \\
\hline $\mathrm{S}_{2} \mathrm{M}$ & 5 & 2 & 1 & 1 & 1 & 20 & 1.8 \\
\hline Total & 11 & 4 & 1 & 2 & 2 & 20 \\
\hline
\end{tabular}

Table 20

Therefore $\mathbf{H O}_{4}$ having five statement are accepted i.e. there exists no difference between mother of school $1 \&$ mother of school 2 towards his or her visually impaired child. 
Statement-1 (Table-21): I have no hesitation regarding the education of my blind child.

$S_{1} F S_{2} F \& S_{1} M S_{2} M$

\begin{tabular}{|c|c|c|c|c|c|c|c|}
\hline & SA & A & NC & D.A. & S.D.A & Total & Chi square \\
\hline $\begin{array}{l}\mathrm{S}_{1} \mathrm{~F} \\
\mathrm{~S}_{2} \mathrm{~F}\end{array}$ & 9 & 6 & 2 & 2 & 1 & 20 \\
\hline $\begin{array}{c}\mathrm{S}_{1} \mathrm{M} \\
\mathrm{S}_{2} \mathrm{M}\end{array}$ & 6 & 6 & 2 & 0 & 0 & 20 & \\
\hline Total & 15 & 12 & 4 & 2 & 1 & 40 & 3.42 \\
\hline
\end{tabular}

Table 21

Statement -2 (Table-22): I am very much sympathetic for the education of my blind child.

$S_{1} F S_{2} F \& S_{1} M S_{2} M$

\begin{tabular}{|c|c|c|c|c|c|c|c|}
\hline & SA & A & NC & D.A. & S.D.A & Total & Chi square \\
\hline $\begin{array}{l}\mathrm{S}_{1} \mathrm{~F} \\
\mathrm{~S}_{2} \mathrm{~F}\end{array}$ & 12 & 4 & 0 & 2 & 2 & 20 & \\
\hline $\begin{array}{l}\mathrm{S}_{1} \mathrm{M} \\
\mathrm{S}_{2} \mathrm{M}\end{array}$ & 15 & 2 & 0 & 2 & 1 & 20 & \\
\hline Total & 27 & 6 & 0 & 4 & 3 & 40 & 2.24 \\
\hline
\end{tabular}

Table 22

Statement -3 (Table-23): I want to give all sympathetic for the education of my blind child.

$S_{1} F S_{2} F \& S_{1} M S_{2} M$

\begin{tabular}{|c|c|c|c|c|c|c|c|}
\hline & SA & A & NC & D.A. & S.D.A & Total & Chi square \\
\hline $\begin{array}{l}S_{1} \mathrm{~F} \\
\mathrm{~S}_{2} \mathrm{~F}\end{array}$ & 11 & 5 & 0 & 2 & 2 & 20 & \\
\hline $\begin{array}{l}\mathrm{S}_{1} \mathrm{M} \\
\mathrm{S}_{2} \mathrm{M}\end{array}$ & 11 & 6 & 1 & 2 & 0 & 20 & \\
\hline Total & 22 & 11 & 1 & 4 & 2 & 40 & 3.8 \\
\hline
\end{tabular}

Table 23

Statement-4 (Table-24): I think tuition is required for my blind child.

$S_{1} F S_{2} F \& S_{1} M S_{2} M$

\begin{tabular}{|c|c|c|c|c|c|c|c|}
\hline & SA & A & NC & D.A. & S.D.A & Total & Chi square \\
\hline$S_{1} \mathrm{~F}$ & 9 & 6 & 2 & 2 & 1 & 20 & \\
$\mathrm{~S}_{2} \mathrm{~F}$ & 12 & 4 & 2 & 2 & 0 & 20 & \\
\hline $\begin{array}{l}\mathrm{S}_{1} \mathrm{M} \\
\mathrm{S}_{2} \mathrm{M}\end{array}$ & & & & & & \\
\hline Total & 21 & 10 & 4 & 4 & 1 & 40 & 1.82 \\
\hline
\end{tabular}

Table 24

Statement -5 (Table-25): I do not want that my blind child participate in different co curricular activities.

$\mathbf{S}_{1} \mathbf{F} \mathbf{S}_{2} \mathbf{F} \& \mathbf{S}_{\mathbf{1}} M \mathbf{S}_{2} M$

\begin{tabular}{|c|c|c|c|c|c|c|c|}
\hline & SA & A & NC & D.A. & S.D.A & Total & Chi square \\
\hline $\mathrm{S}_{1} \mathrm{~F}$ & 8 & 3 & 2 & 2 & 5 & 20 \\
$\mathrm{~S}_{2} \mathrm{~F}$ & & 4 & 1 & 2 & 2 & 20 & \\
\hline $\mathrm{S}_{1} \mathrm{M}$ & 11 & & & & & \\
$\mathrm{~S}_{2} \mathrm{M}$ & 19 & 7 & 3 & 4 & 7 & 40 & 4.16 \\
\hline Total & & &
\end{tabular}

Table 25

Therefore $\mathrm{HO}_{5}$ having five statement are accepted i.e there exists no difference between fathers of school $1 \&$ school 2 and mothers of school $1 \&$ school 2 mother towards his or her visually impaired child. 
Presentation of the statements by the figure for each hypothesis.

H01:

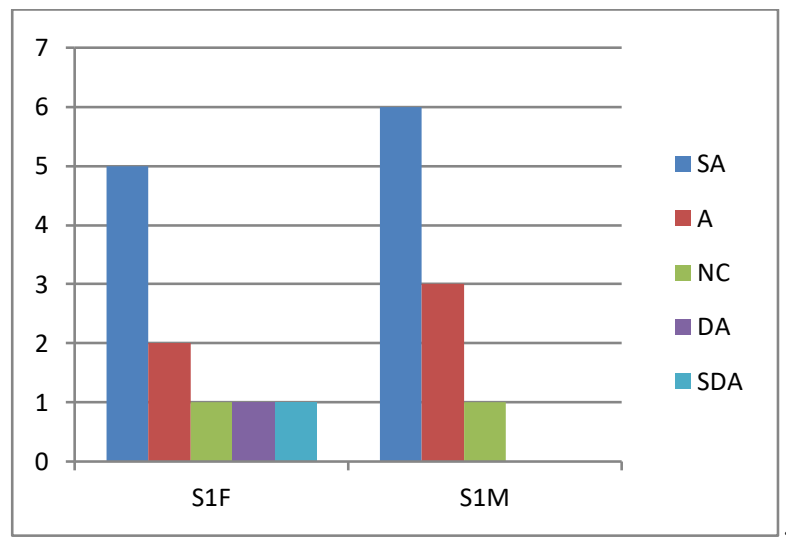

Fig 1(Statement -1)

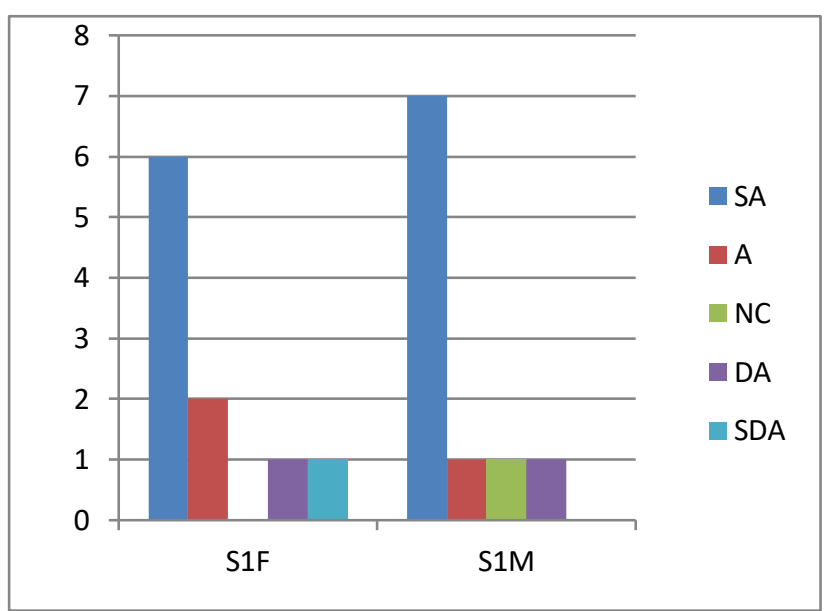

Fig 3 (Statement-3)

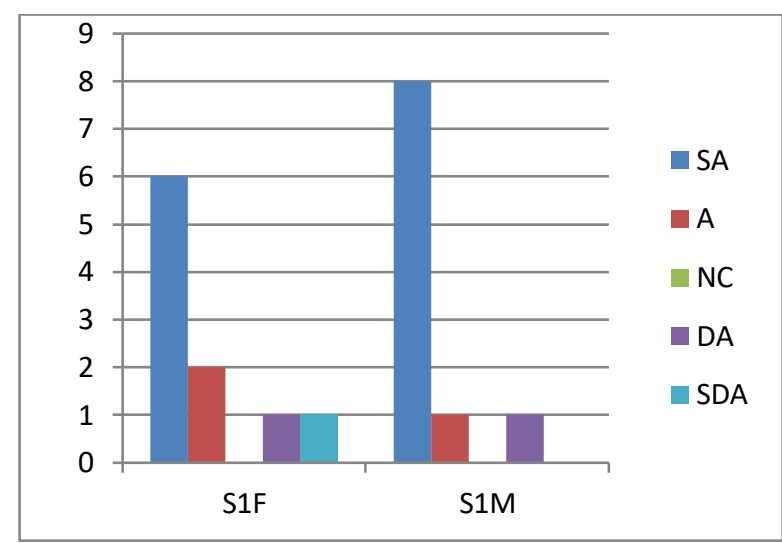

Fig 2 (Statement-2)

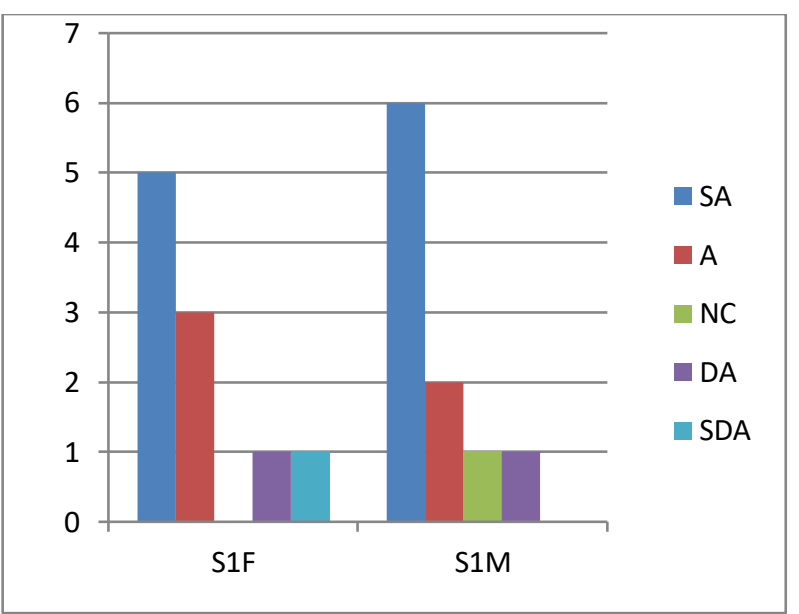

Fig 4 (Statement-4)

$\mathrm{HO}_{2}$

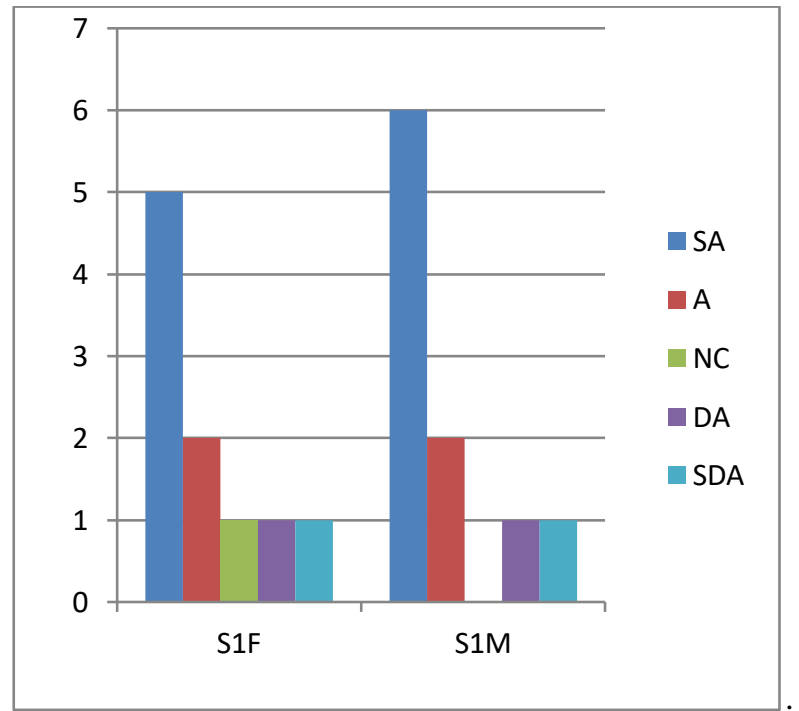

Fig 5(Statement-5)

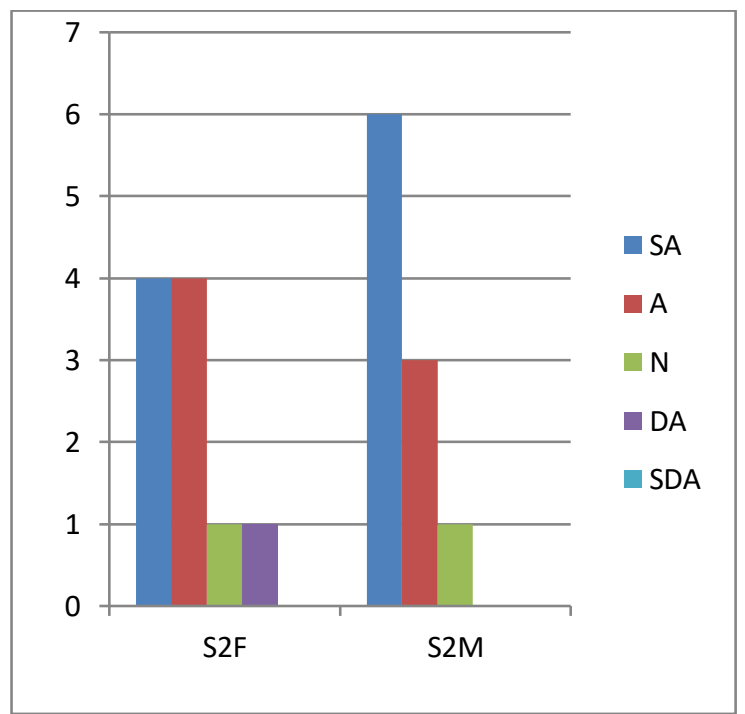

Fig 6(Statement-1) 
ISSN No:-2456-2165

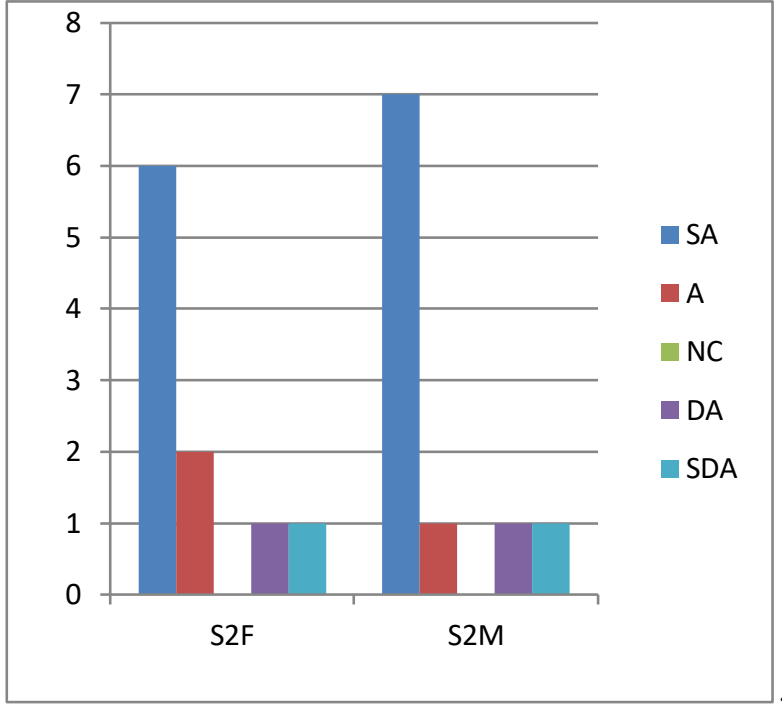

Fig 7(Statement-2)

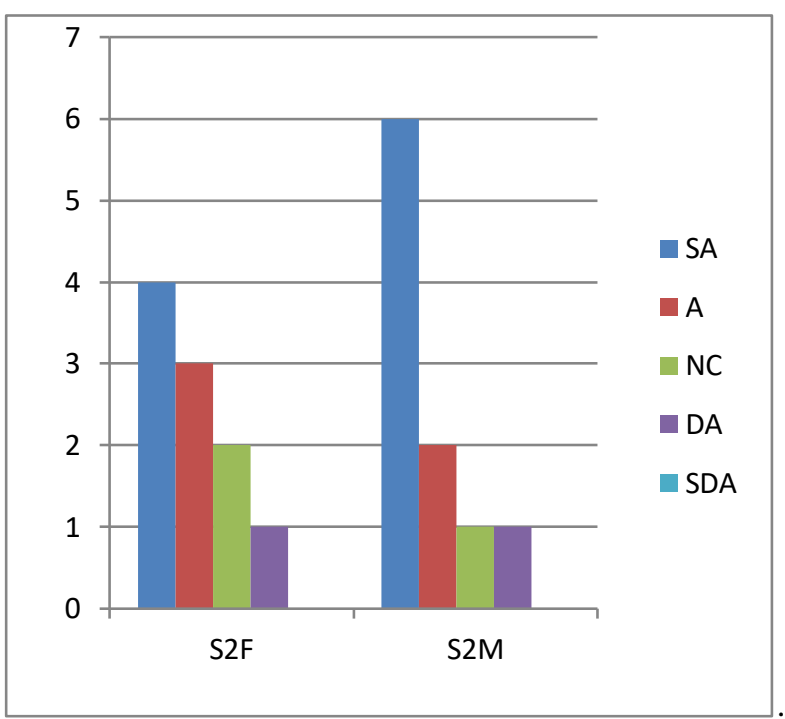

Fig 9 (Statement-4)

$\mathrm{HO}_{3}$

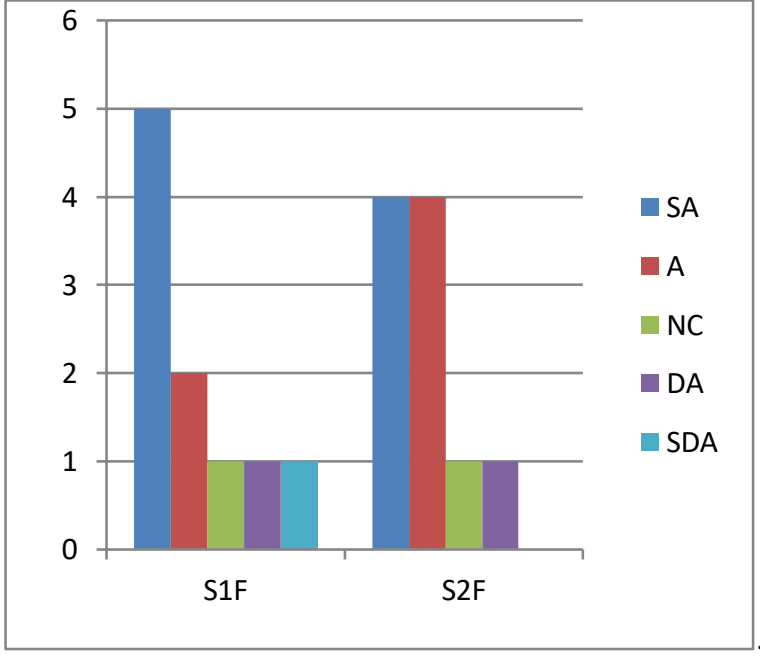

Fig 11 (Statement-1)

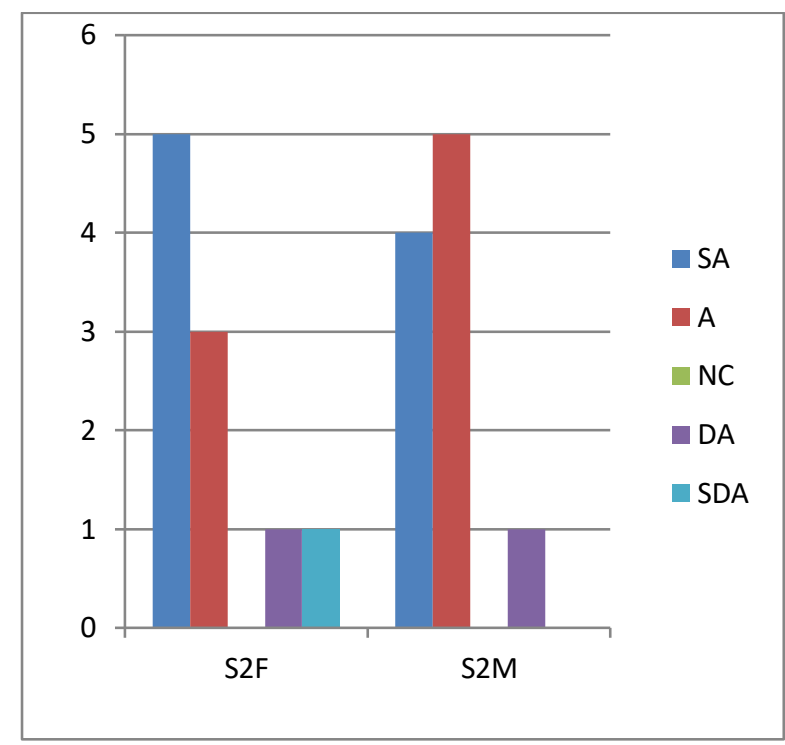

Fig 8(Statement-3)

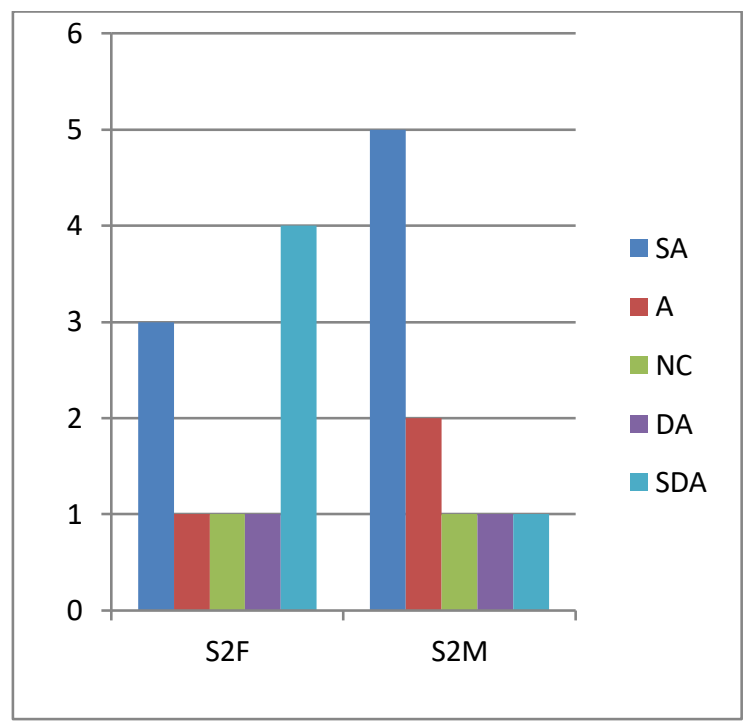

Fig 10 (Statement-5)

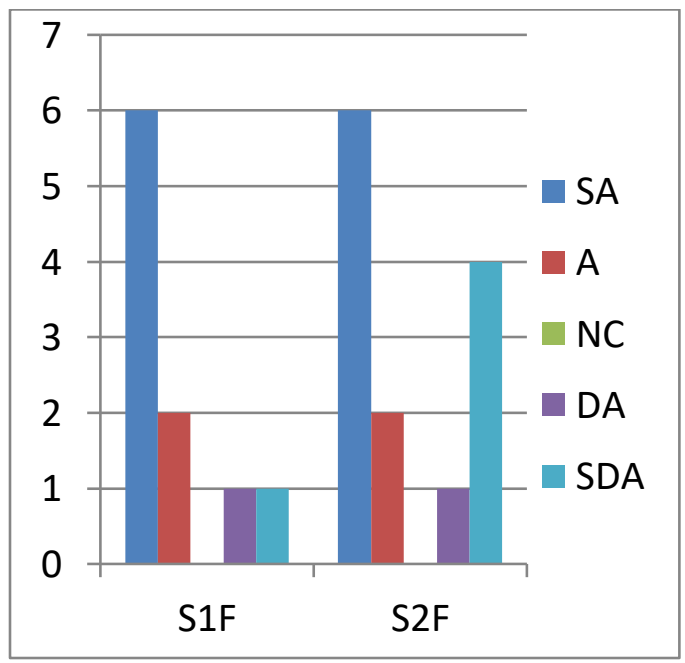

Fig 12(Statement-2) 
ISSN No:-2456-2165

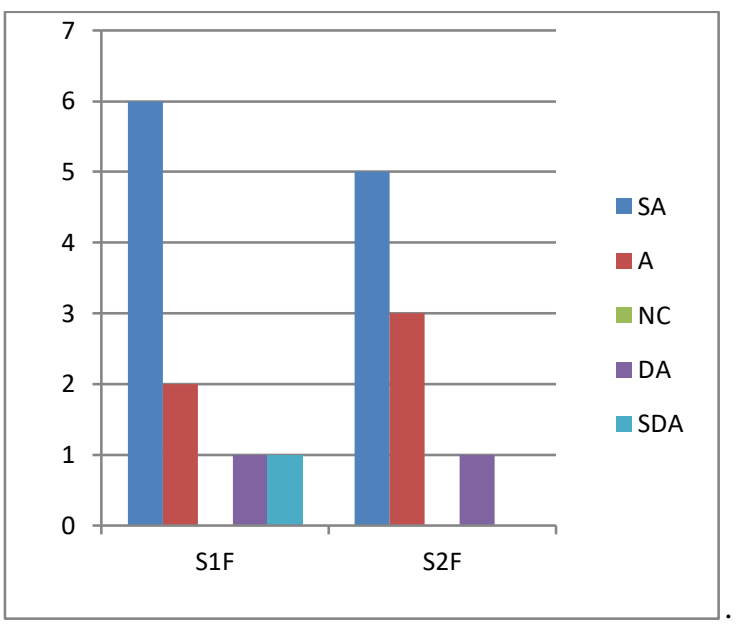

Fig 13 (Statement-3)

$\mathrm{HO}_{4}$

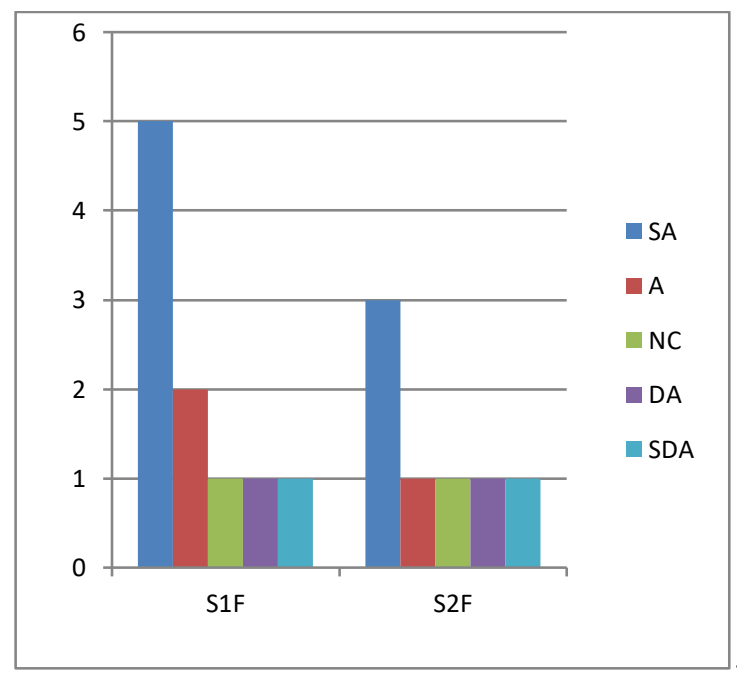

Fig 15(Statement-5)

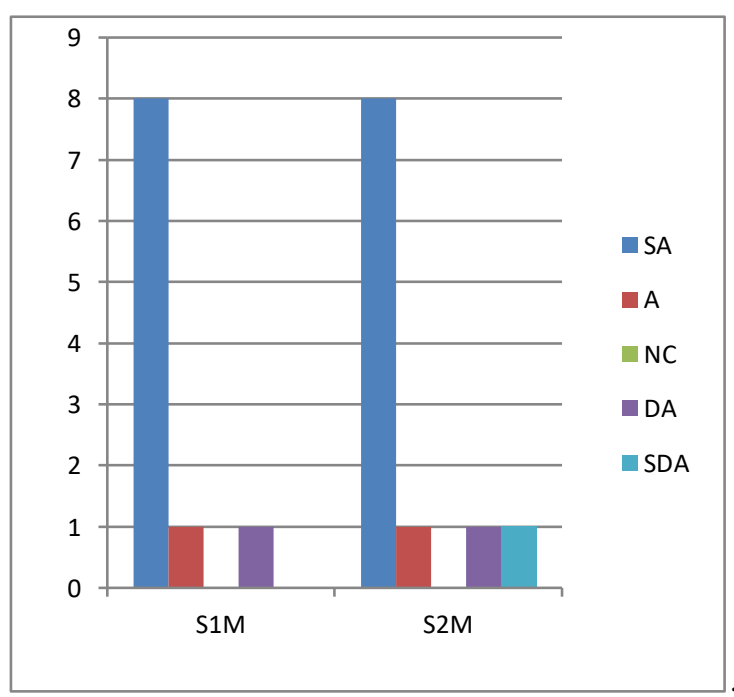

Fig 17(Statement-2)

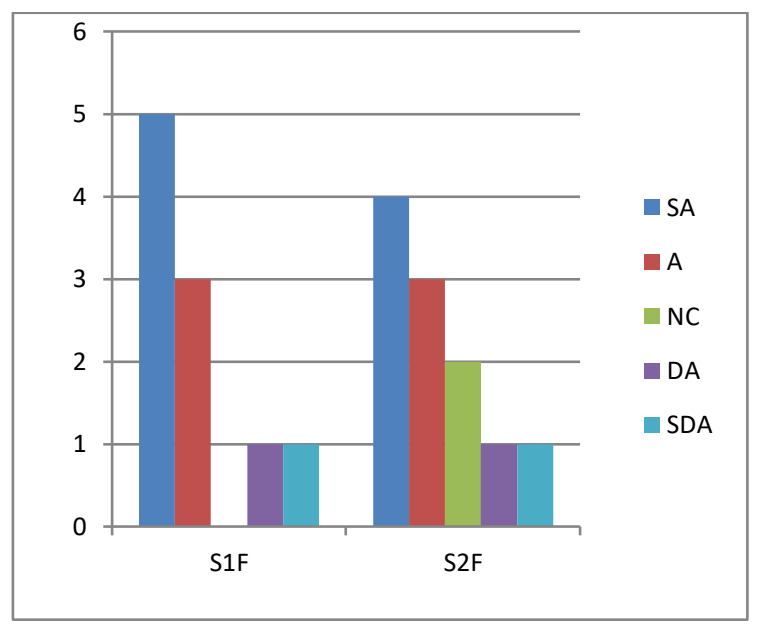

Fig 14(Statement-4)

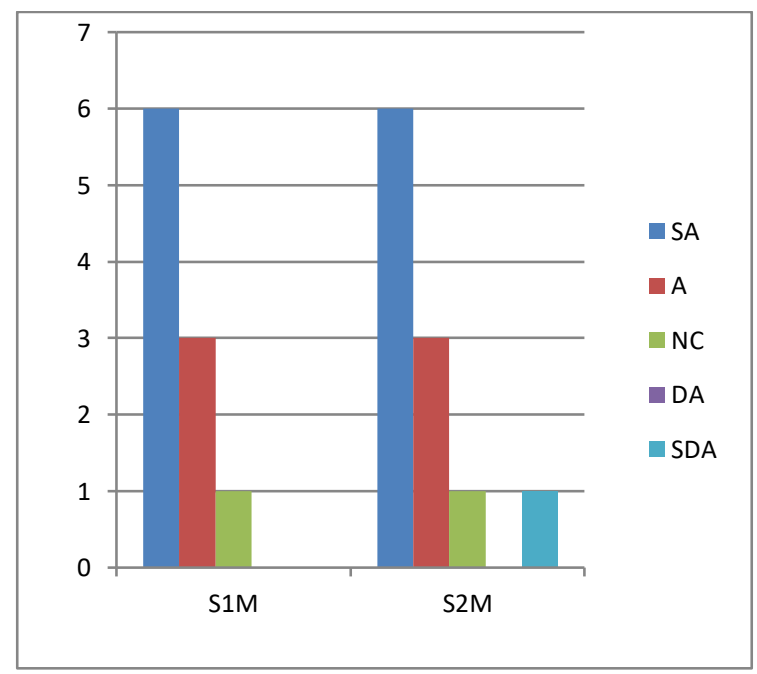

Fig 16(Statement-1)

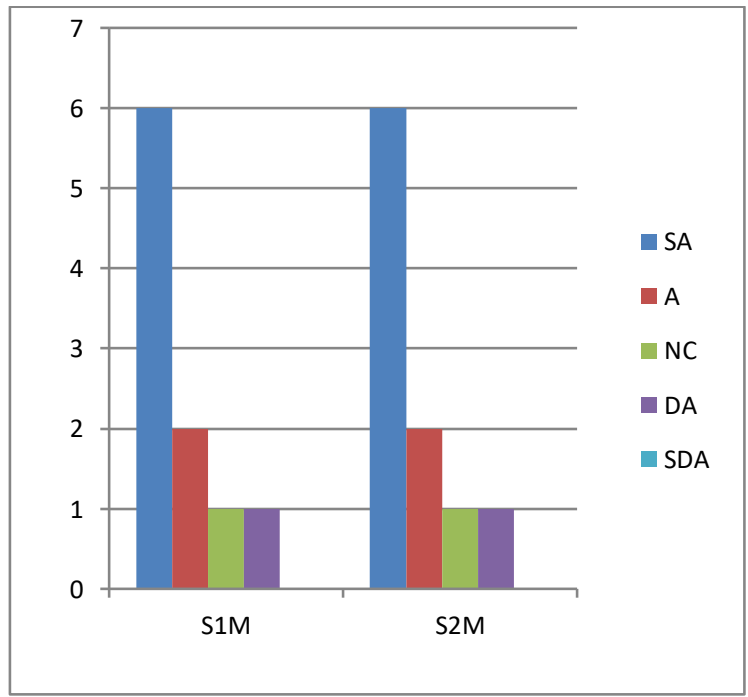

Fig 18(Statement-3) 


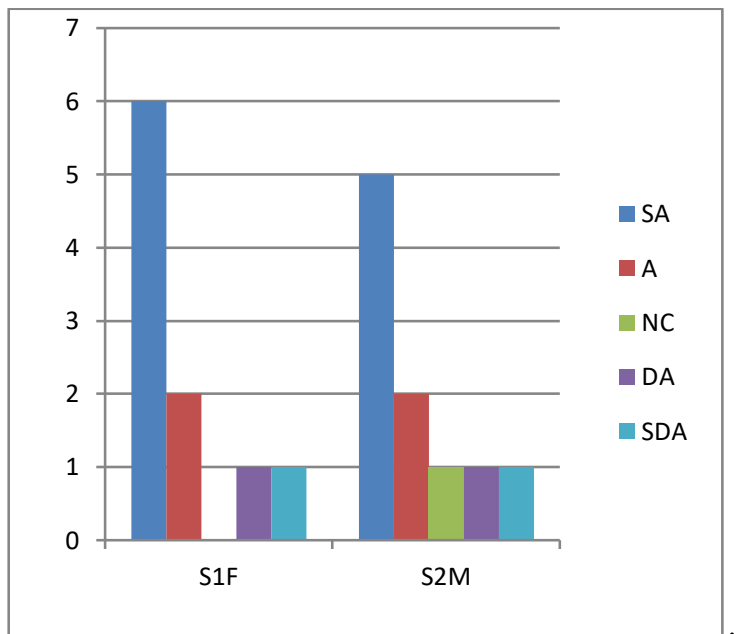

Fig 19(Statement-4)

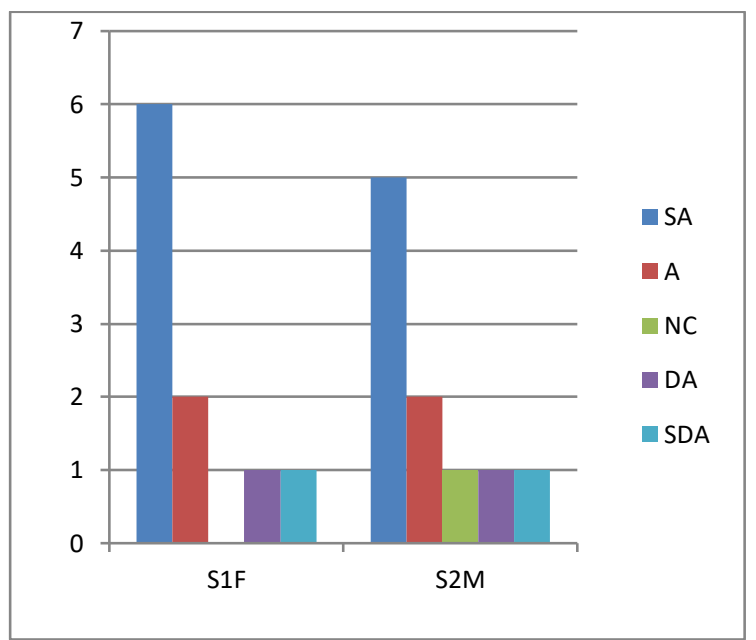

Fig 20(Statement-5)

H05

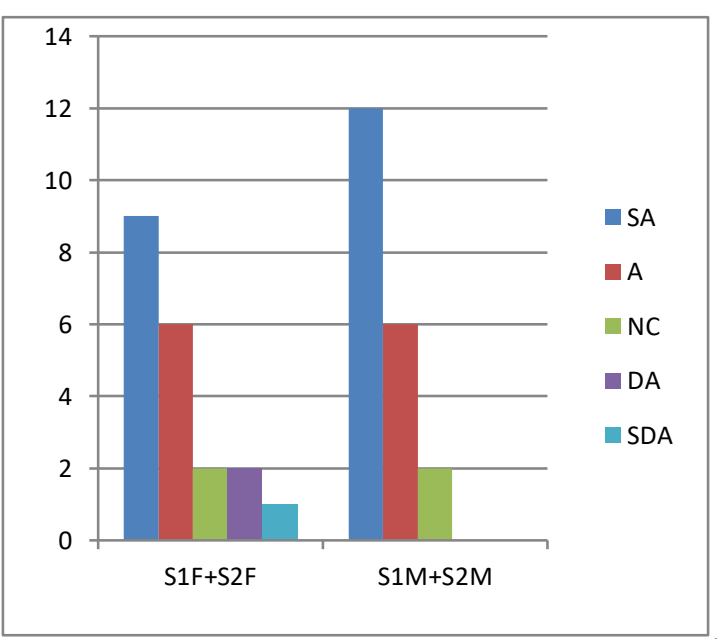

Fig 21(Statement-1)

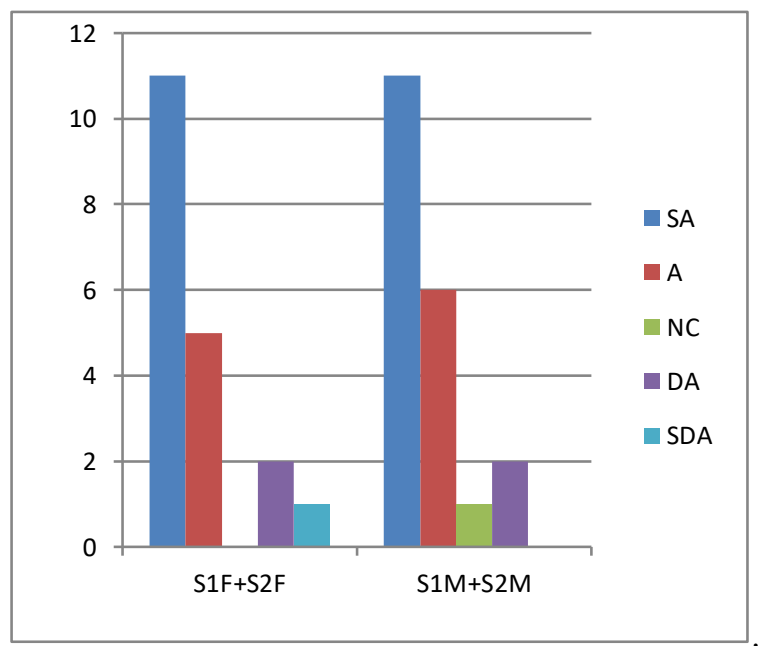

Fig 23(Statement-3)

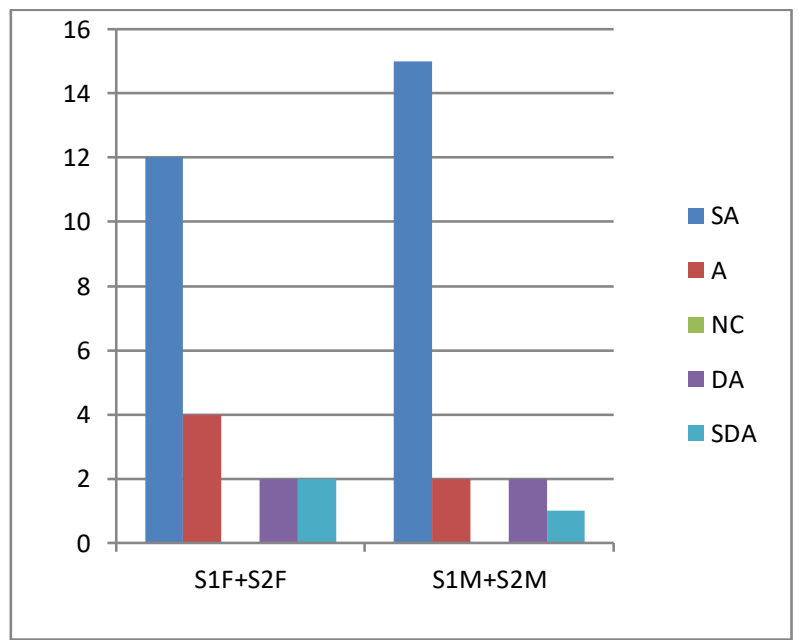

Fig 22(Statement-2)

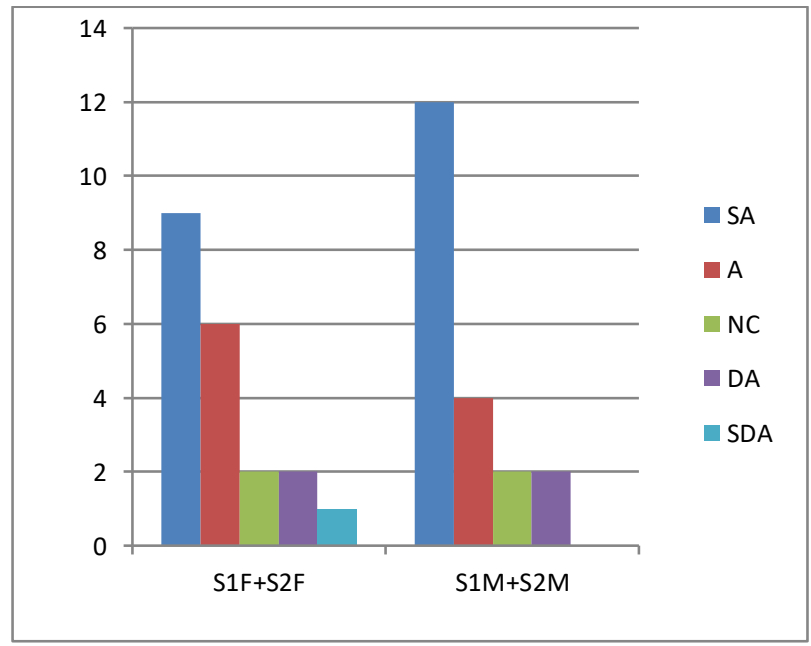

Fig 24(Statement-4) 
ISSN No:-2456-2165

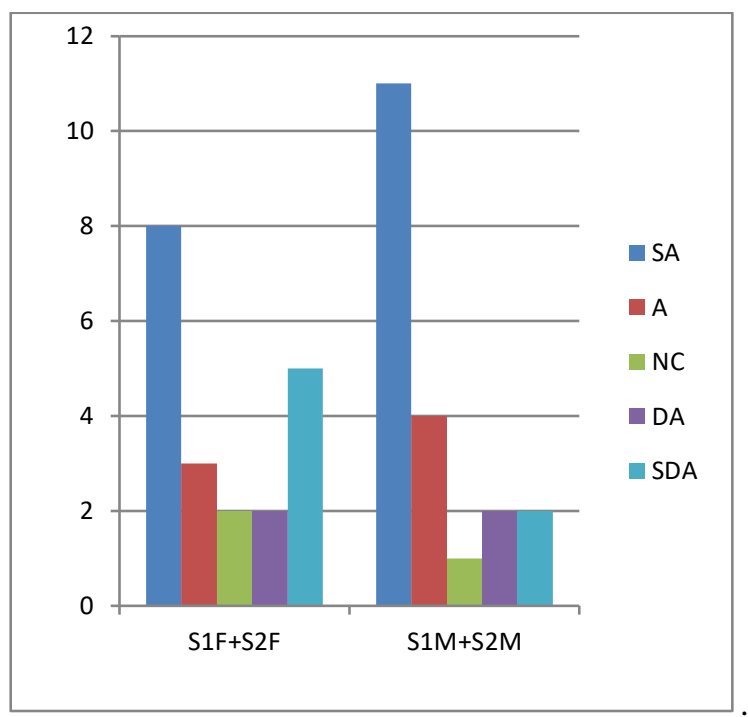

Fig 25(Statement-5)

\section{FINDINGS}

From the table-1: It is found that chi square experimental value is 2.9 and that of chi square critical at 0.05 level $=16.9$ and at $0.1=21.6$ respectively.

So, the statement 1 is accepted, therefore there exists no significant difference in attitude between fathers \& mother s of school 1 .

From the table :2: - It is found that chi square except value is 2.6 and that of chi square critical at 0.5 level $=$ 16.9 and at 0.1 level $=21.6$ respectively.

So, the statement 2 is accepted, therefore there exists no significant difference in attitude between fathers \& mothers of school 1 .

From the table-3: It is found that chi square except the value is 2.38 and that of chi square critical at 0.5 level = 16.9 and at 0.1 level $=21.6$ respectively.

So, the statement 3 is accepted, therefore there exists no significant difference in attitude between fathers \& mothers of school 1 .

From the table-4: - It is found that chi square except value is 3 and that of chi square critical at 0.5 level $=16.9$ and at 0.1 level $=21.6$ respectively.

So, the statement 4 is accepted, therefore there exists no significant difference in attitude between father $s$ \& mothers of school 1 .

From the table-5: It is found that chi square except the value is 1.8 and that of chi square critical at 0.5 level $=$ 16.9 and at 0.1 level $=21.6$ respectively.

So, the statement 5 is accepted, therefore there exists no significant difference in attitude between fathers \& mothers of school 1.
From the table-6: - It is found that chi square except value is 3.17 and that of chi square critical at 0.5 level $=$ 16.9 and at 0.1 level $=21.6$ respectively.

So, the statement 1 is accepted ,therefore there exists no significant difference in attitude between father $s$ \& mother s of school 2 .

From the table-7: It is found that chi square except the value is 1.92 and that of chi square critical at 0.5 level $=16.9$ and at 0.1 level $=21.6$ respectively.

So, the statement 2 is accepted, therefore there exists no significant difference in attitude between fathers \& mothers of school 2.

From the table-8: - It is found that chi square except value is 3.5 and that of chi square critical at 0.5 level = 16.9 and at 0.1 level$=21.6$ respectively.

So, the statement 3 is accepted, therefore there exists no significant difference in attitude between fathers \& mothers of school 2 .

From the table-9: It is found that chi square except the value is 1.92 and that of chi square critical at 0.5 level $=16.9$ and at 0.1 level $=21.6$ respectively.

So, the statement 4 is accepted, therefore there exists no significant difference in attitude between fathers \& mother s of school 2.

From the table-10: - It is found that chi square except value is 2.62 and that of chi square critical at 0.5 level = 16.9 and at 0.1 level $=21.6$ respectively.

So, the statement 5 is accepted, therefore there exists no significant difference in attitude between fathers \& mothers of school 2 .. 
From the table-11: It is found that chi square except the value is 2.6 and that of chi square critical at 0.5 level $=$ 16.9 and at 0.1 level $=21.6$ respectively.

So, the statement 1 is accepted, therefore there exists no significance difference in attitude between father $s$ of school $1 \& 2$

From the table-12: - It is found that chi square except value is 1 and that of chi square critical at 0.5 level = 16.9 and at 0.1 level=21.6 respectively.

So, the statement 2 is accepted ,therefore there exists no significance difference in attitude between fathers of school $1 \& 2$.

From the table-13: - It is found that chi square except value is 2 and that of chi square critical at 0.5 level $=16.9$ and at 0.1 level $=21.6$ respectively.

So, the statement 3 is accepted, therefore there exists no significant difference in attitude between father $s$ of school $1 \& 2$.

From the table-14: - It is found that chi square except value is 4 and that of chi square critical at 0.5 level $=16.9$ and at 0.1 level=21.6 respectively.

So, the statement 4 is accepted, therefore there exists no significant difference in attitude between father $s$ of school $1 \& 2$.

From the table-15: - It is found that chi square except value is 2.62 and that of chi square critical at 0.5 level $=16.9$ and at 0.1 level $=21.6$ respectively.

So, the statement 5 is accepted, therefore there exists no significant difference in attitude between fathers of school $1 \& 2$.

From the table-16: - It is found that chi square except value is 2 and that of chi square at 0.5 level $=16.9$ and at 0.1 level $=21.6$ respectively.

So, the statement 1 is accepted, therefore there exists no significant difference in attitude between mothers of school $1 \& 2$.

From the table-17: - It is found that chi square except value is 2.6 and that of chi square critical at 0.5 level $=16.9$ and at 0.1 level $=21.6$ respectvely.

So, the statement 2 is accepted, therefore there exists no significant difference in attitude between mother $s$ of school $1 \& 2$.

From the table-18: - It is found that chi square except value is 5.46 and that of chi square critical at 0.5 level $=16.9$ and at 0.1 level $=21.6$ respectively.
So, the statement 3 is accepted, therefore there exists no significant difference in attitude between mothers of school $1 \& 2$.

From the table-19: - It is found that chi square except value is 1 and that of chi square critical at 0.5 level $=16.9$ and at 0.1 level $=21.6$ respectively.

So, the statement 4 is accepted, therefore there exists no significant difference in attitude between mothers of school $1 \& 2$..

From the table-20: - It is found that chi square except value is 1.8 and that of chi square critical at 0.5 level $=16.9$ and at 0.1 level $=21.6$ respectively.

So, the statement 5 is accepted, therefore there exists no significant difference in attitude between mothers of school $1 \& 2$.

From the table-21: - It is found that chi square except value is 3.42 and that of chi square critical at 0.5 level $=16.9$ and at 0.1 level $=21.6$ respectively .

So, the statement 1 is accepted, therefore there exists no significant difference in attitude between fathers of school $1 \& 2 \&$ mother s of school $1 \& 2$.

From the table-22: - It is found that chi square except value is 2.24 and that of chi square critical at 0.5 level $=16.9$ and at 0.1 level $=21.6$ respectively.

So, the statement 2 is accepted, therefore there exists no significant difference in attitude between fathers of school $1 \& 2 \&$ mothers of school $1 \& 2$.

From the table-23: - It is found that chi square except value is 3.8 and that of chi square critical at 0.5 level $=16.9$ and at 0.1 level $=21.6$ respectively.

So, the statement 3 is accepted, therefore there exists no significant difference in attitude between fathers of school $1 \& 2 \&$ mothers of school $1 \& 2$.

From the table-24: - It is found that chi square except value is $1 . .82$ and that of chi square critical at 0.5 level $=16.9$ and at 0.1 level $=21.6$ respectively.

So, the statement 4 is accepted, therefore there exists no significant difference in attitude between fathers of school $1 \& 2 \&$ mothers of school $1 \& 2$.

From the table-25: - It is found that chi square except value is 4.16 and that of chi square critical at 0.5 level $=16.9$ and at 0.1 level $=21.6$ respectively.

So, the statement 5 is accepted, therefore there exists no significant difference in attitude between father $s$ of school $1 \& 2 \&$ mothers of school $1 \& 2$. 


\section{Interpretation of Data:}

HO1 consists of five statements from which it is found that there exists no significant difference in parental attitude(father \& mother) towards the visually impaired children of secondary level in case of school 1 ( Narendrapur Blind Boys' Academy)

Figure 1 to 5 which are related to hypothesis 1 give the same result. Therefore the hypothesis 1 is accepted both statistically \& graphically.

$\mathrm{HO}_{2}$ consists of five statement from which it is found that there exists no significant difference in parental attitude (father \& mother) towards the visually impaired children of secondary level in case of school 2 ( Light House For The Blind)

Figure 6 to 10 which are related to hypothesis 2 give the same result. Therefore the hypothesis 2 is accepted both statistically \& graphically.

$\mathrm{HO}_{3}$ consists of five statement from which it is found that there exists no significant difference in fathers attitude (father of school $1 \& 2$ )towards the visually impaired children of secondary level in case of school $1 \& 2$ (Narendrapur Blinds Boys' Academy \& Light House For The Blind).

Figure 11 to 15 which are related to hypothesis 3 give the same result. Therefore the hypothesis 3 is accepted both statistically \& graphically.

$\mathrm{HO}_{4}$ consists of five statement from which it is found that there exists no significant difference in mothers attitude ( mother of school $1 \& 2$ ) towards the visually impaired children of secondary level in case of school 1 \& 2 (Narendrapur Blind Boys' Academy \& Light House For The Blind )

Figure 16 to 20 which are related to hypothesis 4 give the same result. Therefore the hypothesis 4 is accepted both statistically \& graphically.

H05 consists of five statement from which it is found that there exists no significant difference in( fathers \& mothers attitude of school $1 \& 2$ ) towards visually impaired children of secondary level in case of school 1 \& 2( Narendrapur Blind Boys' Academy \& Light House For The Blind)

Figure 21 to 25 which are related to hypothesis 5 give the same result. Therefore the hypothesis 5 is accepted both statistically \& graphically.

\section{CONCLUSION}

Within the society there may be the different attitudes of fathers \& mothers towards their visually impaired children. But in this study it is found that both fathers \& mothers of two school have the same attitude towards their visually impaired children. The researchers have done the study by taking two blind schools of West Bengal \& the hypothesis are statistically are tested both by statistically $\&$ graphically.

Society wants the same attitude of father $\&$ mother having visually impaired child. So, the societal needs are fulfilled by the study. Not only for the visually impaired children but also any type of exceptional children the same type of opinions are expected from his or her parents.

\section{REFERENCES}

[1]. Aminabhavi, Vijaylaxmi A.(1996). A study of Adjustmental ability of physically Disabled and Abled Students.In Sixth survey of educational Research(1993-2000) Vol.-I. New Delhi: NC ERT-P205.

[2]. Bramsion, P,K. Bruggerman, and G. Pretty,2002 Community and subjective quality of life. International Journal of Disability, Development and Education ,49:385-97.

[3]. Cole ,D.A \& Meyer ,L.H.(1991),Social Integration and Severe Disabilities: A Longitudinal .Analysis of Child Outcomes .The Journal of Special Education.Vol.25 (3).pp.340-50

[4]. Dutt, Gargi , (2001), Social Acceptance and Problems Associated With Mental Retardation .Indian Educational abstracts,vol .6 , No. 1, Jan ...2006,NCERT.

[5]. Green , S.K. and M.R.Shinn.1995. Parent attitudes about special educational and reintegration exceptional children 61:269-81

[6]. Holden .G.W.1995. Parental attitudes toward childrearing .In Handbook of parenting ed .M.H. Bornstgein ,369-92.New Jersey: Lawrence Earlbaum Associates Publishers. 